Abilene Christian University

Digital Commons @ ACU

8-30-2020

Public Attitudes Toward Xenotransplantation: A Theological

Perspective

Vic McCracken

Follow this and additional works at: https://digitalcommons.acu.edu/bible_missions

Part of the Religion Commons 


\title{
Public Attitudes Toward Xenotransplantation: A Theological Perspective
}

\author{
Vic McCracken \\ College of Biblical Studies, Abilene Christian University, Abilene, TX, USA
}

\begin{abstract}
Among the myriad factors contributing to public attitudes toward xenotransplantation, religious belief offers a complex picture. In April 2019, xenotransplantation researchers at the University of AlabamaBirmingham conducted a focus group conversation among 12 area religious leaders. This article offers a theological analysis of the transcript of this conversation. The details of the interactions among the focus group participants sheds light on the manner in which theological belief shapes attitudes toward xenotransplantation. While participants generally recognized and affirmed the potential benefits of xenotransplantation, their support was tempered by an array of concerns emerging from a theological narrative that shaped their moral assessment.
\end{abstract}

\section{KEYWORDS}

Xenotransplantation; religion; theology; public attitudes

Chronic shortages of human transplant organs and tissues contribute to end-stage organ failure for growing numbers of patients. Xenotransplantation - the use of non-human organs as a source for human transplantation - offers a promising solution to this critical problem. While the potential benefits of xenotransplantation research are clear, this promise is not without risks. Cross-species transplantation poses immunological risks to patients, requiring the use of immunosuppressant drugs to inhibit organ rejection. Xenotransplantation increases the possibility of cross-species viral transfer, posing risks to the patient herself and, potentially, to the broader public. The long-term risks of dormant viral infection entail ongoing health monitoring of xenotransplantation recipients. The strange new world wrought by xenotransplantation therapy thus raises numerous ethical challenges in discerning how to properly balance patient autonomy with public health (Anderson, 2006).

Because of the long-term benefits and possible health risks posed by xenotransplantation research, public consent is important. The public needs to be informed of the benefits and risks, and researchers should be committed to ensuring public support for research by those who may reap the benefits or suffer these harms. A failure to account for public attitudes has stymied xenotransplantation research in the past, as for example, in Australia when a complete moratorium was placed on xenotransplantation clinical trials until 2009, a result of a failure to engage and involve the public in an assessment of public health risks (Cook, 2011).

Public attitudes toward xenotransplantation have been generally positive (Hagelin, 2004). Among the myriad factors contributing to public attitudes toward xenotransplantation, however, religious belief offers a complex picture. Some studies suggest that religious activity 
or belief is an insignificant variable with respect to public attitudes toward xenotransplantation (De Bona et al., 2004). Other studies suggest a lower acceptance of xenotransplantation among the religiously active, and among those who oppose xenotransplantation religion is often cited as a main reason for rejection of the procedure (Hagelin, 2004). Researchers need a better grasp of how religious belief impacts the perceptions of citizens as they grapple with the moral import of xenotransplantation (Paris et al., 2018).

In April 2019, researchers at the University of Alabama-Birmingham conducted a focus group made up of 11 Christian ministers and one Muslim religious leader from the Birmingham area. The 75-minute discussion provides a window into how these religious leaders understood the intersection of their religious beliefs with xenotransplantation therapy. The details of the interactions among the focus group participants sheds light on the manner in which theological belief shapes attitudes toward xenotransplantation.

I am a theological ethicist, not a social worker. I have been asked to provide an outsider's "theological" perspective into this focus group discussion. Before doing this, however, I believe it essential to explain the methodological approach I am adopting that has shaped my approach to this task. Often when studying the moral beliefs of religious persons there is a tendency to focus attention on the prescriptions and prohibitions that inform how religious adherents engage the world. To understand religious attitudes toward xenotransplantation in this vein, one needs to attend simply to the prescriptive claims that religious traditions make about the practice - what religious communities permit and prohibit. However, since the 1970s, "narrative theology" has emerged as a prominent approach in the field of Christian theology (Frei, 1974; Lindbeck, 1984). Narrative approaches to theology resist the reductive tendency described above. Religious traditions are not merely collections of propositions, prohibitions, and prescriptions. Rather, religious traditions offer adherents a distinctive "narrative" that helps them make sense of the world. Religious narratives identify the root problem(s) in human life; they point to potential solutions to these problems. Religious narratives provide a sense of moral order to the world, illuminating those things that are most important in life while framing life around shared practices that draw believers ever closer toward a common vision of the good. Religious narratives invite us to see our own mundane, day-to-day experiences as part of a grand, cosmic drama. Religious narratives clarify human experience. They also give rise to new tensions when the stories that religious traditions tell conflict with those other narratives that give shape to our life in this world.

In assessing religious attitudes toward xenotransplantation, I do so as a narrative theologian. Methodologically, this commitment entails three things. First, narrative theology problematizes the idea that it is possible to speak of a singular religious perspective on a topic like xenotransplantation. Because different religious traditions offer their own distinctive accounts of the world, an accurate understanding of religious attitudes toward xenotransplantation entails that we resist the temptation to create a caricature of what "religious" people believe.

Second, narrative theology insists that digging into the "thickness" of religious stories is a critical theological task, an essential prerequisite to doing theology. To understand what religious adherents believe about xenotransplantation requires us to consider with some care the overarching religious narrative that shapes why adherents frame their attitudes as they do. It requires careful attention to the language that adherents employ when talking about xenotransplantation, the ways that this language draws from a larger narrative account of the world. 
Third, because narrative theology insists that proper theological knowledge may be found only in the particularity of differing religious narratives, digging into the particularities of the traditional narratives represented by the Christian and Muslim focus group participants is essential. Such a task would entail a close, critical engagement with multiple religious narratives, a task that is well beyond the limits of what I can accomplish in the space of this essay. For this reason, I have opted to narrow my focus in this essay to the Christian tradition. Because I myself am a Christian ethicist, I am most competent to speak to the particularities of this tradition. Given that 11 of the 12 focus group members are Christian, the transcript data offers more substantial opportunities to demonstrate how narrative theology can offer a window into how religious belief shapes attitudes toward xenotransplantation. To be clear, in focusing primarily on the Christian narrative I am not implying that the contributions of non-Christian voices are unimportant or irrelevant. A fuller presentation of how religious belief informs public attitudes will require a more careful engagement with the theologically rich stories embraced by Muslim, Jewish, Buddhist, Hindu, and other religious persons.

\section{Xenotransplantation, the Imago Dei, and the moral merits of "playing God"}

Given the obvious benefits that might extend from xenotransplantation, it should come as little surprise that focus group participants were generally supportive of the efforts of clinical researchers. Participants acknowledged that xenotransplantation provided a useful remedy to the limited supply of human donor organs. During the focus group, participants variously described xenotransplantation research as "exciting," "a wonderful idea," and several also observed that they would readily accept a xenotransplant organ if needed to ensure their own survival. "Is this something that will have a lasting, positive effect on humanity?" queried one participant. "In that case, this could be a good sign of a breakthrough." As a whole, participants recognized and embraced the potential benefits that xenotransplantation research may have for patients suffering from end-stage organ failure.

This embrace of xenotransplantation, however, was tinged with notes of ambivalence for many in the focus group. When asked to describe their potential concerns, participants quickly tempered their support for xenotransplantation with statements of caution and reservation about the ethical implications of the procedure. Several in the focus group expressed concern about the harms that this therapy might pose to the animals themselves. "I'm feeling hypocritical," said one participant, "... I want them raised for this but I am concerned about them being raised for this." Another participant confessed that while he might consent to receiving a xenotransplant if necessary that doing so would bother his conscience. Participants recognized that their feelings about instrumentalizing animals in this way conflicted with their own frequent consumption of animals as a source for food. "The ethics and the humane treatment of those subjects are still important to me," said one participant, "and I recognize that I will eat a burger later. I get it. I totally get it. I'm inconsistent."

The broader moral concerns raised by participants - and more specifically, the Christian participants who constituted the majority of the focus group - were clearly shaped by theological convictions emerging from a religious narrative that helped them to make sense of the key issues that are at stake in xenotransplantation research and therapy. Not merely a matter of utilitarian calculus - do the costs outweigh the benefits? - xenotransplantation 
raised fundamental questions for religious adherents about humankind's relationship with the natural world. May humans use nature to further human ends? If so, what are the limits of human freedom? What responsibilities do humans have to account for the interests of other beings affected by the pursuit of human interests? The explicitly theological concerns of participants are perhaps best captured by the comment of one member: "The concern is continuing down that trail with science ultimately playing God .... The greatest theological concern would be are we overstepping what the Creator has provided?"

For anyone familiar with the Judeo-Christian creation story, anxieties about the risks of "playing God" will be unsurprising. The ambivalence expressed by religious leaders reflects tensions internal to the Christian tradition's own narrative account of the human person and the natural world. Genesis 1-3 describes the natural world as itself a product of the generative work of a beneficent, loving God: "In the beginning, God created the heavens and the earth" (New Revised Standard Version Bible, 2001, Genesis 1:1). Over the course of six days, God creates a universe of increasing complexity - sun, moon, stars, land and sea, vegetation, and animal species of every kind. God pronounces all of creation to be good (Genesis 1:4, 10, 25). God's labor culminates on the sixth day with the creation of humankind. Unique in all creation, humankind alone is formed in God's own image (Imago Dei), and to humankind alone God gives dominion over all other created things:

Then God said, "Let us make humankind in our image, according to our likeness, and let them have dominion over the fish of the sea, and over the birds of the air, and over the cattle, and over all the wild animals of the earth, and over every creeping thing that creeps upon the earth ... Be fruitful and multiply, and fill the earth and subdue it; and have dominion over the fish of the sea and over the birds of the air and over every living thing that moves upon the earth." God said, "See, I have given you every plant yielding seed that is upon the face of all the earth, and every tree with seed in its fruit; you shall have them for food. And to every beast of the earth, and to very bird of the air, and to everything that creeps on the earth, everything that has the breath of life, I have given very green plant for food." (Genesis 1:26, 28-29)

Thus, in one sense the creation narrative suggests that humans, themselves made in the image of God, are to play God. God commands humankind to subdue creation. As John Paul (1981) states in the Encyclical, Laborem Exercens, the Genesis story elevates human action in nature as itself a reflection of humankind's unique status:

Man is the image of God partly through the mandate received from his Creator to subdue, to dominate, the earth. In carrying out this mandate, man, every human being, reflects the very action of the Creator of the universe. (John Paul, 1981, In the Book of Genesis section, para. 2)

The Creation story reinforces a moral posture that grants priority to human interests, pronouncing a divine blessing on the ways in which humankind may use creation to enhance human wellbeing. From this vantage point, the Christian story provides a narrative framework that makes it possible to see xenotransplantation therapy as just another example of the exercising of proper dominion over a creation gifted to humanity by God.

And yet the story is not so simple. The idea that humans might be "playing God," and the implication that doing so is in some sense an act of transgression, appeals implicitly to a general understanding of human nature that is deeply formed by the conclusion of the Christian creation narrative. The creation myth describes a world in which humans - Adam and Eve - live in harmony with God and one another in the Garden of Eden (Genesis 2:15-25). This ideal state, however, is disrupted by human disobedience. "You may freely 
eat of every tree of the garden," says God, "but of the tree of the knowledge of good and evil you shall not eat, for in the day that you eat of it you shall die" (Genesis 2:17). Gifted every tree of the garden save one, Adam and Eve succumb to the allure of the forbidden tree. A serpent, "more crafty than any other wild animal that the Lord God had made," (Genesis 3:1) explains to the first man and woman that God's command masks an ulterior motive: "for God knows that when you eat of it your eyes will be opened, and you will be like God, knowing good and evil" (Genesis 3:5). Tempted by their own desire to become like God, Adam and Eve eat from the tree, an act that prompts God to cast them from the Garden, the divine-human relationship forever marred by their disobedience.

The creation story renders in narrative form a dialectical reality that according to the Christian tradition is at the heart of the human condition. Adam and Eve's story is not theirs alone; it is the human story, a fitting description of the human condition. Humankind stands above creation as the sole created thing created in God's own image. Humans are capable of rising above the contingencies of life in the natural world, acting in freedom in a way that embodies, to borrow from Christian theologian, Niebuhr (1964), a God-given capacity for self-transcendence. And yet it is precisely in the exercise of this capacity that we find Adam and Eve's propensity - indeed, the propensity of all humanity - to overreach in ways that either falsely deny human creatureliness or claim for humanity what rightfully belongs to God alone. This is the paradox at the heart of Christian anthropology: it is precisely because humans are capable of rising above nature that we are also able to transgress moral limits in willful acts of hubristic excess.

The creation story thus raises two possibilities. Xenotransplantation might well be a practice fully consonant with humanity's proper role as beings created in God's own image. When focus group members embrace the promise of xenotransplantation in their discussion, their comments reflect this possibility. Alternatively, the Creation story offers another possibility, for it may also be the case that xenotransplantation is just another example of hubris, yet another way that humans are striving to become like God. The ambivalence expressed by focus group members reflects the dramatic tension latent in how the story describes humankind's relationship to the natural world.

The creation narrative illuminates two other worries about xenotransplantation expressed by members of the focus group. First, because humankind is created in God's own image, some participants expressed concern about the implications of incorporating non-human tissue into the human person in a way that blurs the uniqueness of human identity. "The research is interesting," noted one participant, "and I don't know much about the research of most of the medical professionals here, but from a ministerial standpoint, the long-term fear would be that we might be creating a Frankenstein."

Another participant suggested that while some forms of xenotransplantation therapy are acceptable, there are clear moral lines that should not be crossed:

No, I think there are two organs that should never be transplanted from animal to human. One of those is the brain which we feel that the mind is something that makes us uniquely human. And of course, the other would be gonads. We couldn't reproduce in piglets when we reproduce, but other than that, kidneys and lungs and hearts, I don't get why there is any theological objection.

This comment reflects some awareness of contemporary Catholic teaching on the topic of xenotransplantation, which similarly stands opposed to transplantation of the head or the 
gonads, procedures that would themselves undermine the uniqueness and dignity of the human person (Pontifical Academy for Life, 2001). In this regard, concerns raised by focus group participants over the potential threats of xenotransplantation on human identity overlap with a parallel debate in contemporary theological circles over transhumanism and the incorporation of technology into the person (Sautermeister, 2015). The worry here is that manipulations of the human self, be they biological incorporation of non-human tissue or the incorporation of non-biological technology for the purpose of self-enhancement, obfuscates the gifted nature of humankind as beings created in God's own image.

Beyond concerns about the impact of xenotransplantation on human identity, focus group members raised a second set of worries that related their moral concerns to a broader angst about human abuse of creation. The Christian concept of human dominion over creation suggests that within nature there is a broad sphere wherein humankind may properly use creation for human ends. While historical Christianity has taken the idea of dominion as the justification for giving priority to human interests over the interests of nonhuman life, contemporary ecological concern has heightened moral anxieties about this facet of the creation story. White's (1967) seminal essay, "The Historical Roots of Our Ecological Crisis," faults the Christian tradition for elevating human mastery over nature in a way that has contributed to immense environmental harm:

Since both science and technology are blessed words in our contemporary vocabulary, some may be happy at the notions, first, that, viewed historically, modern science is an extrapolation of natural theology and, second, that modern technology is, at least partly to be explained as an Occidental, voluntarist realization of the Christian dogma of man's transcendence of, and rightful mastery over, nature. But, as we now recognize, somewhat over a century ago science and technology - hitherto quite separate activities - joined to give mankind powers which, to judge by many of the ecologic effects, are out of control. If so, Christianity bears a huge burden of guilt. (p. 1206)

In the focus group conversation, observations about xenotransplantation frequently merged with broader comments about humanity's adverse impact on the natural environmental. Amid the group discussion of his concerns about xenotransplantation, for example, one participant's attention quickly shifted to problems inherent in industrial food production, practices that are themselves harmful to those whom these practices are supposed to serve:

We can see some of the results of who and how we live now as well, through all of the chickens that grow big. Our children aren't living well and a lot of things that are personal that I see from the mass productions of what we are doing is affecting us as humans and our life span as well. Even obesity. We can grow a chicken in a couple months and then we consume it so fast and I personally believe that there are some problems with that as far as our health is concerned.

Another participant recounted a film documentary in which a local pig farm had dumped waste in a rural community in North Carolina, spreading illness and disease in the local community.

Participants drew parallels between the adverse impact of humans on the natural world and their own unsettled feelings about xenotransplantation.

Concerns about the manner in which dominion over creation quickly devolves into abuse of creation were prominent among focus group participants. In discussing their moral perceptions of human responsibility, participants rarely utilized language of mastery 
over creation, preferring instead language that better reflected the idea of human responsibility to care for creation. Such comments reflect trends in recent biblical scholarship, which have offered a more nuanced understanding of the moral meaning of human dominion than what is reflected in White's (1967) critique. Brueggemann (1982), for example, observes

The 'dominion' here mandated is with reference to the animals. The dominance is that of a shepherd who care for, tends, and feeds the animals. Or, if transferred to the political arena, the image is that of a shepherd king .... Thus the task of "dominion" does not have to do with exploitation and abuse. It has to do with securing the well-being of every other creature and bringing the promise of each to full fruition. (p. 32)

Focus group participants broadly empathized with this view. Noted one participant, humans are called by God to be stewards of creation, a role that heightens the moral responsibility of treating all of creation, including non-human species, well. "I would think it is kind of an honor in a sense, the animal," "that we are called to be stewards of creation. Animals are part of creation of which we have stewardship."

In summary, participants describe the relationship with creation as one fraught with tension. Humans are called to be proper stewards of creation, but frequently, too frequently perhaps, humanity falls short of proper creation care. In his reflections on xenotransplantation, one participant expressed concern not so much with the idea of using animal tissues to enhance human life and more with the idea of industrializing the creation of animals for this specific purpose. The key question that concerned participants in this regard is not whether or not xenotransplantation can serve human ends but whether the corollary practices that make xenotransplantation possible-the factory creation and harvesting of animal organs, for example-embodies proper care for God's creation or is merely the latest example of human abuse of the natural order.

\section{Conclusion}

The Christian creation myth illustrates how concerns about xenotransplantation are not novel; they are entirely appropriate given the dilemma at the heart of the human condition. Humans are created by God in a way that renders us capable of transcendence, but it is in the pursuit of the possibilities inherent in our nature that we persistently overreach. Christian bioethicist Meilaender (2013) observes that Christian anthropology, with its dialectical emphasis on the freedom and finitude intrinsic to human existence, points Christians toward a striking conclusion about the practice of medicine:

\footnotetext{
Understanding our nature in this way, we learn something about how we should evaluate medical "progress." It cannot be acceptable simply to oppose the forward thrust of scientific medicine. That zealous desire to know, to probe the secrets of nature, to combat disease - all that is an expression of our created freedom from the limits of the "given," the freedom by which we step forth as God's representatives in the world. But a moral vision shaped by this Christian understanding of the person will also be prepared to say no to some exercises of human freedom. The never-ending project of human self-creation runs up against the limit that is God. (Meilaender, 2013, pp. 4-5)
}

Xenotransplantation may itself be a fitting example of how humans exercise proper dominion over creation. Alternatively, xenotransplantation might be the latest example of 
human transcendence run amok. Adam and Eve's desire to become "like God" is ours as well. The Christian story offers no ready answer to the question of which interpretation is correct. The Christian story offers instead a framework for a people who, in recognizing the inevitable tensions at the heart of our identity as beings created in God's own image, wrestle together to discern what it means to live as faithful stewards of God's creation.

\section{Acknowledgments}

I am grateful to Melinda Isbell, Research and Instructional Service Librarian at Abilene Christian University, for her copyediting assistance

\section{Conflicts of interest}

The author has no conflicts of interest or financial stake in the research study that is the focus of this article.

\section{References}

Anderson, M. (2006). Xenotransplantation: A bioethical evaluation. Journal of Medical Ethics, 32(4), 205-208. https://doi.org/10.1136/jme.2005.012914

Brueggemann, W. (1982). Genesis. Interpretation commentary series. John Knox Press.

Cook, P. S. (2011). What constitutes adequate public consultation? Xenotransplantation proceeds in Australia. Journal of Bioethical Inquiry, 8(1), 67-70. https://doi.org/10.1007/s11673-010-9269-8

De Bona, M., Canova, D., Rumiati, R., Russo, F. P., Ermani, M., Ancona, E., Naccarato, R., \& Burra, P. (2004). Understanding of and atittudes to xenotransplantation: A survey among Italian university students. Xenotransplantation, 11(2), 133-140. https://doi.org/10.1111/j.1399-3089.2004.00091.x

Frei, H. W. (1974). The eclipse of Biblical narrative. Yale University Press.

Hagelin, J. (2004). Public opinion surveys about xenotransplantation. Xenotransplantation, 11(6), 551-558. https://doi.org/10.1111/j.1399-3089.2004.00172.x

John Paul, I. I. (1981). Laborem exercens. Libreria Editrice Vaticana. http://www.vatican.va/content/ john-paul-ii/en/encyclicals/documents/hf_jp-ii_enc_14091981_laborem-exercens.html

Lindbeck, G. (1984). The nature of doctrine: Religion and theology in a postliberal age. Westminster John Knox Press.

Meilaender, G. (2013). Bioethics: A primer for Christians (3rd ed.). William B. Eerdmans.

New revised standard version bible. (2001). National Council of Churches.

Niebuhr, R. (1964). The nature and destiny of man, volume I: Human nature. Charles Scribner's Sons.

Paris, W., Seidler, J. H., FitzGerald, K., Padela, A. L., Cozzi, E., \& Cooper, D. K. C. (2018). Jewish, Christian, and Muslim theological perspectives about xenotransplantation. Xenotransplantation, 25(3), 1-8. https://doi.org/10.1111/xen.12400

Pontifical Academy for Life. (2001). Prospects for xenotransplantation: Scientific aspects and ethical considerations. http://www.vatican.va/roman_curia/pontifical_academies/acdlife/documents/rc_ pa_acdlife_doc_20010926_xenotrapianti_en.html

Sautermeister, J. (2015). Xenotransplantation from the perspective of moral theology. Xenotransplantation, 22(3), 183-191. https://doi.org/10.1111/xen.12157

White, L. (1967). The historical roots of our ecological crisis. Science, 155(3767), 1203-1207. https:// doi.org/10.1126/science.155.3767.1203 